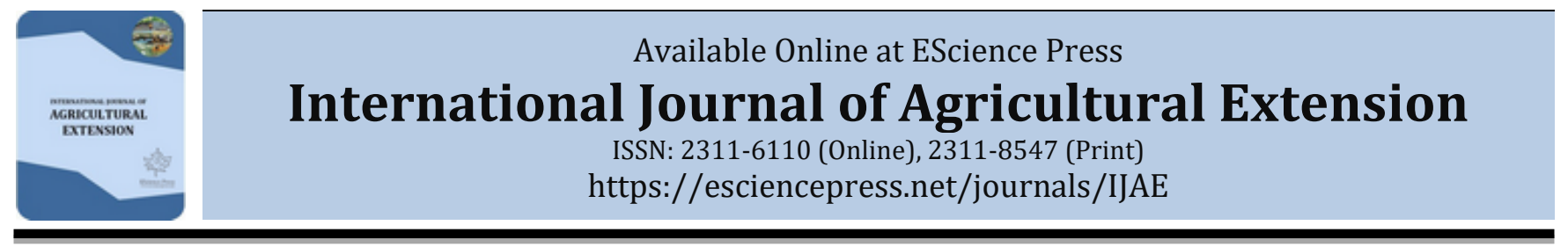

\title{
FACTORS INFLUENCING THE ADOPTION OF CONSERVATION AGRICULTURE PRACTICES AMONG SMALLHOLDER FARMERS IN MOZAMBIQUE
}

\author{
a,b Oscar Chichongue, cAndré Pelser, bJohan van Tol, bChris du Preez, bGert Ceronio* \\ ${ }^{a}$ Mozambique Agricultural Research Institute (IIAM), P.O. Box 3658, Maputo, Mozambique. \\ ${ }^{b}$ Department of Soil, Crop and Climate Sciences, University of the Free State, Bloemfontein, 9300, South Africa \\ ${ }^{c}$ Department of Sociology, University of the Free State, Bloemfontein, 9300, South Africa.
}

*Corresponding Author Email: ochichongue@gmail.com

\section{A B S T R A C T}

This study aimed to identify the factors that influence smallholder farmers' decisions to adopt four different conservation agriculture (CA) practices (i.e. minimum tillage, intercropping, cover cropping and crop rotation) in Mozambique. A non-probability sampling approach, incorporating both purposive and accidental sampling types, was followed. Three agro-ecological regions, followed by four provinces, were purposely selected. In addition, Accidental sampling was used to select 616 smallholder farmers from 38 communities in the three agro-ecological regions where CA projects were historically implemented by several NGO institutions. A questionnaire was administered to the 616 selected smallholder farmers. A descriptive logit model was applied in STATA to determine the probability of respondents adopting CA practices. The findings show that $44.6 \%$ of smallholder farmers adopted one or more of the CA practices, and $55.4 \%$ did not. It was also clear that most farmers did not adopt all components CA. Results obtained revealed that household size, animal ownership, communication assets (such as television, radio, and cell phone) and group membership had a positive influence on CA adoption. Interestingly, female-headed households were more likely to adopt CA. Awareness of soil health decline is an important factor determining adoption. The study concluded that the reasons for adoption are site-specific and a 'blanket approach' to promote adoption of CA is unlikely to be successful.

Keywords: Agro-ecological region, cover cropping, crop rotation, intercropping, logit model minimum tillage.

\section{INTRODUCTION}

In sub-Saharan Africa (SSA) the use of unsustainable farming practices, such as excessive soil tillage with no soil covers, have led to a decrease in soil fertility, accelerated erosion, and degradation of arable land. This resulted in decreased yields and food insecurity (Hobbs, 2007; Nkala, 2012). Traditional cultivation practices adopted by smallholder farmers in southern Africa have become less sustainable with increasing population growth and escalating food demand. In Mozambique, around $68 \%$ of the population live in rural areas and are smallholder farmers (AGRA, 2015). Agriculture is the main driver of the country's economy (World Bank, 2006; Mucavele, 2009), although only $15.7 \%$ of the arable land is cultivated (Filipe \& Kring, 2011). Since the agricultural sector in Mozambique is characterized by small farm sizes and soil degradation, conservation agriculture (CA) is advocated as a viable production system which can assist smallholder farmers to increase the sustainability and productivity of crop production practices and ultimately cope with food insecurity.

The promotion of CA practices in southern Africa started many decades ago. Thus, overall aims were reducing soil degradation, increasing crop yield, minimizing the risk of crop failure, and thereby increasing food insecurity. In general, CA is based on three principles namely: 1) minimal soil disturbance, 2) maintaining a permanent soil cover using at least 30\% of crop residues (Berger et al., 2008, Muchinapaya, 2012) and 3) crop rotation or intercropping (Giller et al., 2009; Thierfelder et al., 2013). Conservation agriculture, therefore, aims to improve the use of agricultural resources through the combined management of soil, water, and biological resources. Despite the benefits and continued efforts by 
national and international organizations to promote the adoption of CA practices in Sub Sahara Africa, the adoption rate among smallholder farmers is still very low. Usually, only some of the CA principles are reported to be adopted on the farm level (Hobbs, 2007; Giller et al., 2009). These selective adoption practices have elicited controversy surrounding the benefits of CA. Different studies (e.g., Gowing \& Palmer, 2008; Giller et al., 2009) have indicated that benefits from the adoption of CA can only be fully realized when all principles are applied simultaneously.

Several socio-economic factors (e.g. age, gender, household head experience, education level, access to credit and inputs, and labor availability) and biophysical characteristics (e.g. soil fertility, soil erosion, rainfall pattern, temperature) have been identified as primary constraints limiting CA adoption (Giller et al., 2009; Chiputwa et al., 2011; Holden \& Quiggin, 2016).

The overall aim of this study was to determine the socioeconomic, biophysical, and institutional factors that influence farmers' decisions to adopt CA practices. Establishing which of these factors impact CA adoption under different environmental and socio-economic conditions, could assist extension providers to identify constraints to CA adoption. Addressing these constraints are likely to increase adoption rates.

\section{METHODOLOGY}

Study area and sampling procedure: In this study, a non-probability, multistage Purposive Sample was used due to the accessibility of respondents and their knowledge of the topic in question (i.e., CA). The choice of a Purposive Sample was motivated by the researchers' interest in the opinion of a specific group, and therefore the need to locate all qualifying cases of a highly specific population. This helped to reduce the chances of biases (Sarantakos, 1998). Mozambique is divided into ten agro-ecological regions based on climate, soil type, altitude, and farming characteristics. The study was limited to only three of these ten agro-ecological regions, viz. R2, R7, and R10 (Figure 1), where CA projects were implemented by several institutions (e.g. World Bank, FAO) in the past. Four provinces (Inhambane, Niassa, Nampula, and Zambézia) in those three agro-ecological zones were purposely selected based on the exposure of farmers to existing CA projects. In these provinces the following districts were purposely selected to cover the three agro-ecological regions: Malema in Nampula and Cuamba in Niassa to cover R7; Gurúè and Namarroi in
Zambézia and Lichinga in Niassa to represent R10 and Inharrime in Inhambane to represent R2 (Figure 1). In these districts, CA practices were actively introduced in 2014 to approximately 12000 smallholder farmers living in 38 communities under an 'Agricultural Productivity Program for Southern Africa' (APPSA) sub-project funded by the World Bank. The objective of the APPSA project was to increase the availability of improved agricultural technologies in Mozambique, Malawi, and Zambia. An APPSA sub-project aimed at promoting CA practices among smallholder farmers in four provinces of Mozambique. Based on the 12000 participants of this sub-project in three agro-ecological zones a sample of 616 smallholder farmers, who were either adopters or non-adopters of CA practices, were accidentally selected from these 38 communities; thus representing $5 \%$ of the targeted farmers. Because the sample was not drawn randomly and also not in accordance with the requirements of probability sampling, it means that the findings cannot be extrapolated to the target population of 12000 smallholder farmers. Although, in this case, the (larger than statistically required) sample size of 616 suggests a confidence interval (error level) of only 3.8\% when using a confidence level of $95 \%$, the findings are still limited to the 616 respondents - a common limitation of non-probability sampling types. All the districts receive unimodal rainfall between October and April ranging from 800 to $2000 \mathrm{~mm}$. Agricultural production is predominantly rainfed and with smallholder farmers relying on subsistence agriculture (MAE, 2005a, b, c, d).

Methods: Data were collected through face-to-face interviews among the selected rural households using a questionnaire that was administered between September and October 2016. This questionnaire was first pre-tested on 40 households in different areas, after which it was refined to enhance validity. The questionnaire contained both open-ended and closedended questions. Trained enumerators conducted interviews under the supervision of the research team. At each selected household, a questionnaire was administered to the household member with the most experience in farming operations. The questionnaire was designed to capture data about socio-economic characteristics, biophysical characteristics, as well as institutional factors that were thought to influence the adoption of CA practices.

Data analysis: Descriptive and econometric data were 
analyzed using STATA statistical software version 15 (StataCorp, 2017). Descriptive statistics of smallholder farmer adopters and non-adopters of CA practices were conducted, which included frequency means minimum/maximum values and percentages. For econometric analysis, a logit model or logistic regression model was used.

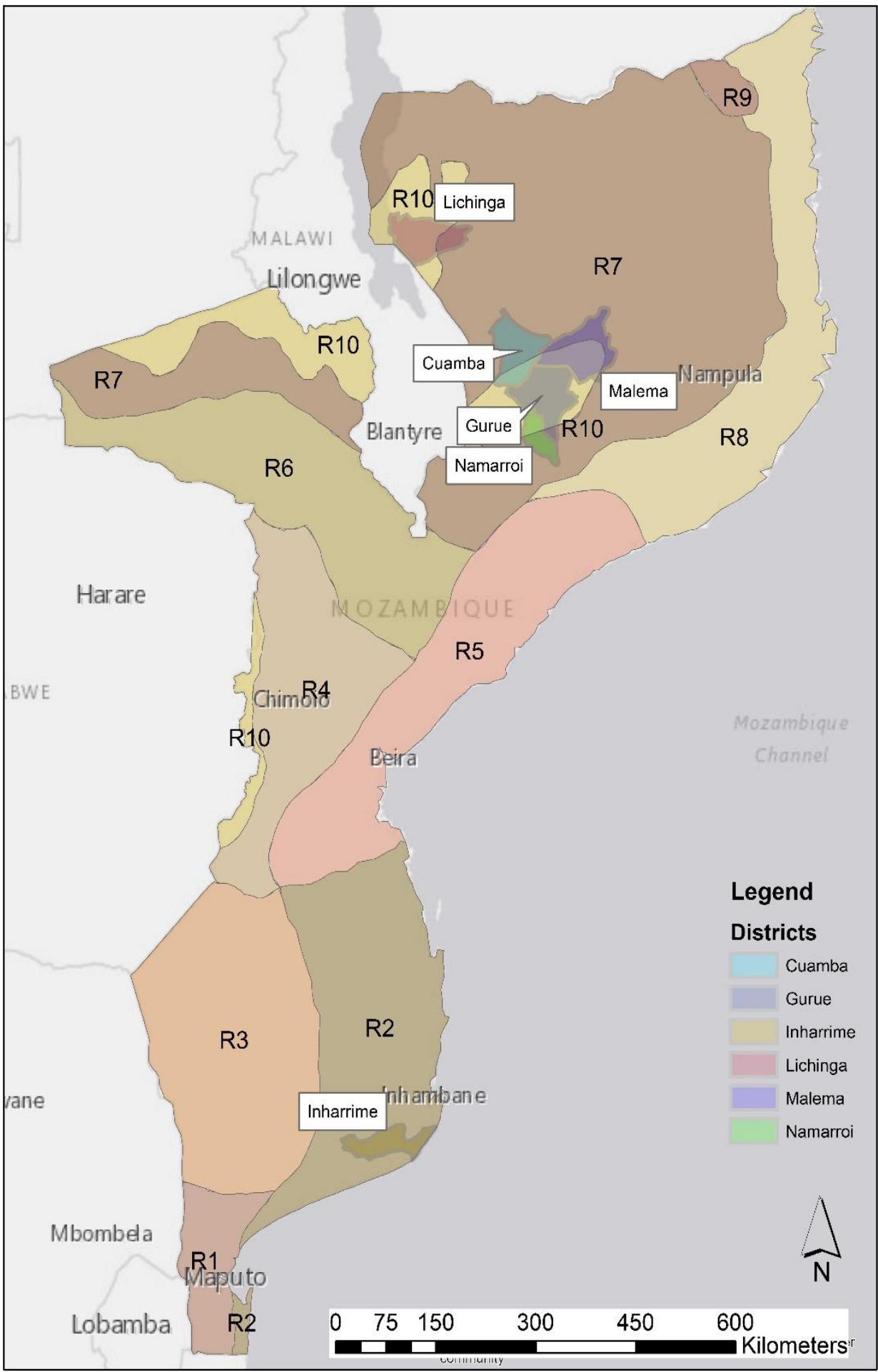

Figure 1. Agro-ecological regions of Mozambique and locations of districts where the study was conducted. 
Analytical framework: The adoption of improved technology is affected by several factors, such as socioeconomic, biophysical, and institutional characteristics (Sheikh et al., 2003). For a smallholder farmer to adopt improved technology or new practices, there must be an incremental benefit when compared to existing technology or practices (Mudiwa, 2011; Jacobs et al., 2018).

Table 1. Description and unit of variables used in logistic regression model (logit model).

\begin{tabular}{|c|c|c|}
\hline Dependent variables & Variable description & Expected effect \\
\hline$\overline{Y^{*}}$ & Farmer practicing CA practices (dummy: $1=$ yes $0=$ otherwise) & \\
\hline $\mathrm{Y}^{* *}$ & Farmer practicing intercropping (dummy: $1=$ yes $0=$ otherwise) & Determined by \\
\hline $\mathrm{Y}^{* * *}$ & $\begin{array}{l}\text { Farmer practicing minimum tillage (dummy: } 1=\text { yes } 0= \\
\text { otherwise) }\end{array}$ & $\begin{array}{l}\text { explanatory } \\
\text { variables }\end{array}$ \\
\hline $\mathrm{Y}^{* * * *}$ & Farmer practicing cover crops (dummy: $1=$ yes $0=$ otherwise) & \\
\hline \multirow[t]{3}{*}{$\mathrm{Y}^{* * * * *}$} & Farmer practicing crop rotation (dummy: $1=$ yes $0=$ otherwise) & \\
\hline & Explanatory variables & \\
\hline & Socio-economic characteristics & \\
\hline Age (X1) & Age of household head (years) & $+/-$ \\
\hline Gender (X2) & Gender of the household head ( $1=$ Male $0=$ female $)$ & + \\
\hline Household size (X3) & Number of household members ( $\geq 15$ years) & + \\
\hline Education (X4) & Household head's education level ( $1=$ literate $0=$ otherwise $)$ & + \\
\hline Experience (X5) & $\begin{array}{l}\text { Adequate farming experience of the household head }(1 \geq 10 \\
\text { years } 0<10 \text { years) }\end{array}$ & $+/-$ \\
\hline Labor demand (X6) & $\begin{array}{l}\text { Inadequate labor (high labor demand) (dummy: } 1=\text { yes } 0= \\
\text { otherwise) }\end{array}$ & + \\
\hline Occupation (X7) & $\begin{array}{l}\text { Household head's primary occupation is agriculture (dummy: } 1 \\
=\text { yes } 0=\text { otherwise) }\end{array}$ & $+/-$ \\
\hline Income (X8) & $\begin{array}{l}\text { Average annual household income (measured in Meticais \& } \\
\text { converted to USD }(\$) \text { ) }\end{array}$ & $+/-$ \\
\hline Animal ownership (X9) & Animal ownership (dummy: 1 = yes $0=$ otherwise) & + \\
\hline Communication assets (X10) & Means to access information (dummy: $1=$ yes $0=$ otherwise) & + \\
\hline \multirow[t]{2}{*}{  } & $\begin{array}{l}\text { Participation in farmer associations (dummy: } 1=\text { yes } 0= \\
\text { otherwise) }\end{array}$ & + \\
\hline & Biophysical constraints & \\
\hline Farm size (X12) & Farm size (ha) & + \\
\hline Fertility (13) & $\begin{array}{l}\text { Farmers' perception of change in soil fertility and soil erosion } \\
\text { (dummy: } 1=\text { yes } 0=\text { otherwise) }\end{array}$ & + \\
\hline Climate(X14) & $\begin{array}{l}\text { Farmers' perception of change in rainfall patterns and } \\
\text { occurrence of extreme temperatures (dummy: } 1=\text { yes } 0= \\
\text { otherwise) }\end{array}$ & + \\
\hline & Institutional constraints & \\
\hline Land tenure (15) & Lack of land tenure security ( $1=$ if secure $0=$ otherwise) & + \\
\hline Training (X16) & $\begin{array}{l}\text { Limited access to research and technical assistance (dummy: } 1= \\
\text { yes } 0=\text { otherwise) }\end{array}$ & + \\
\hline$\beta 1 . . \beta n$ & Coefficients of independent variables X1.....Xn & \\
\hline$\alpha$ & Intercept & \\
\hline$\varepsilon$ & Random error term & \\
\hline í & Ith observation in the sample & \\
\hline
\end{tabular}


Smallholder farmers will adopt the full CA package or more of the components of the CA system if expected benefits are more than the benefits under conventional tillage practices. The few studies on CA in Mozambique (e.g., Famba, 2010; Thierfelder et al., 2013; Grabowski, 2011) reported that smallholder farmers tended to adopt some of the components, usually the crop rotation or intercrop and crops residues. We defined a CA adopter as a farmer who used at least two CA practices (minimum tillage, cover crops, and crop rotation) on his/her fields. Intercropping has been identified as an ancient and traditional farming method, and smallholders from target sites have been using it for a long time as a mean of increasing crop yields per unit land area, reduce weeds and control pests. Therefore, intercropping practices were not considered in the general adoption regression model to avoid bias from this practice.

According to Okello et al., (2012) and Knowler and Bradshaw (2007), there are many approaches for estimating the response of dummy dependent variables. Examples are the linear probability model (LPM), multiple classification analysis, logit model, multinomial logit model, probit model, ordinary least squares, random effects, generalized least squares (GLS), stepwise regression, the Crag model and no parametric chi-square. The application of regression methods depends largely on the measurement scale of the outcome variables and the validity of the model assumptions. The outcome variables include continuous scale, binary measure, or ordered category.

The objective of this study was to capture the relationship between the four CA practices (dependent variables) and socio-economic, biophysical, and institutional characteristics (independent variables) factors influencing adoption. The logit model was therefore used as it allows the analysis of farmers' decisions across more than two categories in the independent variable. Moreover the probabilities for the adoption of different CA practices can be determined (Ayuya et al., 2012). The logit model or logistic regression model is also favoured in several adoption studies because it is generally easier to interpret than other models and can predict the adoption probability of any technology (Adeogun et al., 2008).

Model variables: The variables, which were considered important for the adoption of CA practices, are presented in Table 1, where each one is explained. These variables were used in the logit model that estimates the factors influencing the adoption of CA practices and is specified as follows:

$Y=\alpha+\beta 1 X 1 i+\beta 2 X 2 i+\beta 3 X 3 i+\beta 4 X 4 i+\beta 5 X 5 i ́+\beta 6 X 6 i+$

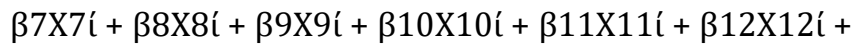

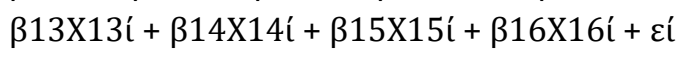

\section{RESULTS AND DISCUSSION}

Descriptive analysis: Of the 616 smallholder farmers who participated in the study, 341 were non-adopters, and 275 were adopters of at least two CA practices. Results from the descriptive analysis of the components of CA practices revealed that 15.8, 17.2, 38.6, and 78.7\% of the household practiced minimum tillage, cover crops, crop rotation, and intercropping, respectively. Among the interviewed farmers intercropping was the most adopted component of CA practices. The descriptive results that include the household socio-economic characteristics of the sample are summarised in Table 2. A total of 403 male-headed (65.42\%) and 213 femaleheaded (34.58\%) households were interviewed. Of the male-headed households, $48.39 \%$ were adopters, and $37.56 \%$ female-headed households adopted CA practices. The average age of adopters was 45.26 years, and of non-adopters, it was 43.31. The youngest adopter was 18 years old and the oldest 80 years. For nonadopters, the youngest was 20 years and the oldest 85 years old. The average farming experience for the whole sample was 19.84 years, with an average of 19 on years for adopters and 20.46 years for non-adopters. Household size averaged five members per household for adopting households and four members for nonadopting households.

With increased education, farmers are more likely to accept and adopt new technology. Only $24 \%$ of the respondents had no formal education, implying that $76 \%$ of the respondents went to school. The highest level of education of the household heads was secondary education $(3.73 \%)$, i.e., none of the respondents had tertiary education. A very large proportion of farmers (53.90\%) did not finish primary education. Most of the farmers who have no formal education were nonadopters (60.14\%).

The overall farm size of the average household's cropped land was 2.26 ha. Adopters typically had more cropped land (2.43 ha) when compared to non-adopters (2.11 ha). About $87 \%$ of the households depended on agriculture to generate an income. The average annual incomes for all respondents are USD 332.57 per 
household. Non-adopters had a lower farm income (USD 307.77) compared to adopters (USD 363.32). The generation of income plays a critical role in financing the adoption of improved agricultural practices. Farmer associations have the potential to influence the adoption decision. Overall, $18.51 \%$ of farmers were members of farmer associations, of which $56.14 \%$ were adopters, and $43.86 \%$ were non-adopters.

Table 2. Socio-economic characteristics of the smallholder farmers.

\begin{tabular}{|c|c|c|c|}
\hline Variable & Total $(n=616)$ & Adopter $(n=275)$ & Non-adopter $(\mathrm{n}=341)$ \\
\hline \multicolumn{4}{|l|}{ CA Practices } \\
\hline - Minimum Tillage & 100 & 15.75 & 84.25 \\
\hline - Cover crops & 100 & 17.21 & 82.79 \\
\hline - Crop Rotations & 100 & 38.64 & 61.36 \\
\hline - Intercropping & 100 & 78.73 & 21.27 \\
\hline \multicolumn{4}{|l|}{ Farmers' gender (\%) } \\
\hline - $\quad$ Males & 65.42 & $48.39(31.66) 1$ & $51.61(33.76)$ \\
\hline - Females & 34.58 & $37.56(12.99)$ & $62.44(21.60)$ \\
\hline \multicolumn{4}{|l|}{$\overline{\text { Age }}$} \\
\hline - Mean & 44.18 & 45.26 & 43.31 \\
\hline - Minimum & 18 & 18 & 20 \\
\hline - $\quad$ Maximum & 85 & 80 & 85 \\
\hline Average farming experience (Years) & 19.84 & 19.07 & 20.46 \\
\hline Average household size & 4.50 & 5.01 & 4.03 \\
\hline \multicolumn{4}{|l|}{ Farmers' highest education level (\%) } \\
\hline - Never attended school & 24.02 & $39.86(9.58)$ & $60.14(14.45)$ \\
\hline - Attended formal school & 75.98 & $46.15(35.06)$ & $53.85(40.90)$ \\
\hline Average farm size per household (ha) & 2.26 & 2.43 & 2.11 \\
\hline \multicolumn{4}{|l|}{ Source of household income (\%) } \\
\hline - On-farm activities & 86.85 & $44.86(38.96)$ & $55.14(47.89)$ \\
\hline - Off-farm activities & 13.15 & $43.21(5.68)$ & $56.79(7.47)$ \\
\hline Farmers' estimated annual income 2 & $\$ 332.57$ & $\$ 363.32$ & $\$ 307.77$ \\
\hline \multicolumn{4}{|l|}{ Farmer associations (\%) } \\
\hline - No & 81.49 & $42.03(34.25)$ & $57.97(47.24)$ \\
\hline - Yes & 18.51 & $56.14(10.39)$ & $43.86(8.12)$ \\
\hline
\end{tabular}

\section{Econometric analysis}

Factors influencing the adoption of CA practices: Table 3 presents the results of the logit regression model for the factors that influence the adoption of CA practices among the farmers. The Hosmer-Lemeshow test was performed to test the goodness of fit, and the model was statistically significant, confirming that the model fitted well $(\mathrm{HL}=4.30)$. The model was tested for multicollinearity, and $82.3 \%$ of the explanatory variables were accurately explained. The Breusch-Pagan and Cook-Weisberg test for heteroskedasticity were performed to test the null hypothesis, when the error variances are equal or as an alternative when the error variances are a multiplicative function of one or more variables. A large chi-square would indicate the presence of heteroscedasticity. In this study, the chisquare value was small (0.46), indicating heteroskedasticity was not a problem (or at least that if it was a problem, it was not a multiplicative function of the predicted values). The general results from the model Table 3 (A) show that the adoption of at least two CA practices had statistically significant values from five variables. These were: gender of the household head, household size, animal ownership, communication assets, farmer membership, and perception about decreasing soil fertility. Results show that the variables 
household size, animal ownership, communications assets, and farmer membership were positively related to the likelihood of a smallholder farmer adopting CA practices. Two variables, gender of the household head and perception about decreasing soil fertility, influenced the adoption of CA practices negatively.

Gender of the household head: In SSA household heads are usually the main decision-makers who decide on the adoption of improved technologies. Male-headed households, in general, have a higher probability for the adoption of improved technologies and because of their social and cultural position in society. They also enjoy preferential access to information compared to femaleheaded households (Bazezew, 2015). Although the majority of female-headed households were non-adopters (Table 2), this study found that female headed households were significantly more likely to adopt CA practices than their male counterparts (Table 3(A)). Women have been described in some studies (Bamire et al., 2002) as the "unseen" labor force and the unrecognized backbone of the family and national economy. Olayemi \& Ikpi (1995) reported that women have socio-cultural restrictions limiting their ability to access resources and thus affecting their demand and supply of technology to improve their productive capacities.

Household size: In this study, the adoption of CA practices was found to be influenced positively and statistically significantly by household size. In most countries in SSA, smallholder farmers rely on family labor for crop production. Household size is therefore associated with the availability of labor for farm operations and plays a critical role in the adoption of any agricultural practice (Bamire et al., 2002; Idrisa et al., 2012). A larger household was expected to have a positive effect on adoption compared to smaller households (Bisangwa, 2013; Ng`ombe et al., 2014), which was indeed the case in this study (Table 2).

Animal ownership: Animal ownership was found to be an important predictor for the adoption of CA practices. Animal ownership is an important source of financial capital and wealth. The variable was found to be statistically significant and positively related to the likelihood of adoption of CA practices. Bizunhe (2012) and Mengstie (2009) reported similar results.

Communication assets: Ownership of communication media such as radio, television, and mobile phones were found to have a statistically significant and positive effect on the adoption of CA practices. The results imply that the more household farmers are exposed to media, the more they are likely to choose improved technologies for use on their farms. These results agree with those reported by Lwoga et al., (2011) and Ng`ombe et al., (2014), who found mass media was a suitable channel for acquiring information for large numbers of farmers.

Farmer membership: As expected, farmer membership had a positive and significant effect on the adoption of CA practices. This suggests a positive association between CA practice adoption and farmer membership. Farmers' participation in agricultural associations or groups enhances their interaction and enables them to gain knowledge of proper agricultural practices. Formation of an association or cooperative is a secure means to obtain social capital and ensure the promotion and adoption of new agricultural technologies (Mwangi et al., 2015; Bamire et al., 2002).

Decreasing soil fertility and increasing of soil erosion: Unawareness of soil degradation had a significant negative effect of this variable on the adoption of CA practices. This implied that farmers who were not aware of the decline in soil fertility and deterioration of soil due to erosion were less likely to adopt CA practices. They obviously do not see the need to improve soil fertility nor decrease erosion. Tadesse and Belay (2004), and Fentie et al., (2013) reported positive and significant effects in the adoption of CA practices when farmers were aware of soil erosion problems and declining soil fertility. The fertile soil generates extra yield and income required to provide for household consumption and the purchase of inputs and labor (Vanlauwe et al., 2014).

Factors influencing the adoption of minimum tillage: Conventional tillage is characterized by hand hoe cultivation with repetitious of hand tilling to a required soil depth while with minimum tillage the strip is ripped in the planting lines. For adoption of minimum tillage, five variables were significant at the 5 and 10 percent levels (Table 3 (B)). The age of the household head and ownership of animals were found positively correlated with adoption of minimum tillage. Male-headed households were less likely to adopt minimum tillage as denoted by the negative correlation. Interestingly, perception of declining soil fertility and the changing climate had a statistically significant, but negative, impact on the decision to adopt minimum tillage. The age of the farmers significantly influenced adoption of 
minimum tillage, where older smallholder farmers were more likely to adopt this practice. According to Bamire et al., (2002) and Mengstie (2012) older farmers are more likely to adopt new technologies (soil and water conservation practices) such as minimum tillage because they have more experience and knowledge that gained over the years. In addition, they have land ownership rights and capital because credit agencies trust them more than younger farmers. Animal holding is associated with the prosperity of the smallholder farmer in developing countries. A previous study by Chiputwa et al., (2011) in Zimbabwe, indicated that a smallholder farmer with cattle was able to raise capital for the acquisition of zero-tillage equipment, like seeders, as well as herbicides. Similar results were reported by Bizunhe (2012) and Mengstie (2009), who found a positive association between animal ownership and adoption of soil and water conservation practices.

Table 3. Logit model factors influencing farmers' decision to adopt CA practices.

\begin{tabular}{|c|c|c|c|c|c|c|c|c|c|c|}
\hline \multirow[t]{2}{*}{ Variables } & \multicolumn{2}{|c|}{$\begin{array}{c}\text { General CA } \\
\text { adoption }(\mathrm{A})\end{array}$} & \multicolumn{2}{|c|}{$\begin{array}{l}\text { Minimum tillage } \\
\text { (B) }\end{array}$} & \multicolumn{2}{|c|}{$\begin{array}{c}\text { Cover crops } \\
\text { (C) }\end{array}$} & \multicolumn{2}{|c|}{$\begin{array}{l}\text { Crop rotations } \\
\text { (D) }\end{array}$} & \multicolumn{2}{|c|}{ Intercrops (E) } \\
\hline & Coef. & SE & Coef. & $\mathrm{SE}$ & Coef. & SE & Coef. & SE & Coef. & $\mathrm{SE}$ \\
\hline \multicolumn{11}{|c|}{ Socioeconomic factors } \\
\hline $\begin{array}{l}\text { Age of the } \\
\text { household head }\end{array}$ & 0.004 & 0.007 & $0.017^{*}$ & 0.009 & 0.007 & 0.238 & $-0.014^{* *}$ & 0.007 & -0.006 & 0.009 \\
\hline $\begin{array}{l}\text { Gender of the } \\
\text { household head }\end{array}$ & $-0.308^{*}$ & 0.186 & $-0.467^{*}$ & 0.267 & 0.046 & 0.009 & -0.059 & 0.190 & $-0.55^{* *}$ & 0.218 \\
\hline Household size & $0.061^{* *}$ & 0.026 & -0.005 & 0.032 & -0.002 & 0.030 & 0.020 & 0.026 & 0.051 & 0.034 \\
\hline Education & 0.264 & 0.210 & 0.158 & 0.286 & 0.319 & 0.280 & 0.071 & 0.215 & $0.471^{* *}$ & 0.243 \\
\hline Experience & 0.323 & 0.221 & -0.361 & 0.292 & $-0.6^{* *}$ & 0.270 & $0.689 * * *$ & 0.233 & 0.247 & 0.264 \\
\hline Labor demand & 0.303 & 0.197 & 0.313 & 0.277 & $0.476^{*}$ & 0.269 & $-0.340^{*}$ & 0.200 & $0.590^{* *}$ & 0.233 \\
\hline Occupation & 0.145 & 0.253 & -0.241 & 0.326 & 0.387 & 0.357 & 0.087 & 0.260 & $0.680^{* *}$ & 0.286 \\
\hline Income & -0.000 & 0.000 & 0.000 & 0.000 & 0.000 & 0.000 & 0.000 & 0.000 & $0.000^{*}$ & 0.000 \\
\hline Animal ownership & $0.390^{* *}$ & 0.200 & $0.622^{* *}$ & 0.291 & 0.205 & 0.264 & $0.485^{* *}$ & 0.210 & 0.058 & 0.245 \\
\hline $\begin{array}{l}\text { Communication } \\
\text { assets }\end{array}$ & $0.450^{* *}$ & 0.182 & -0.147 & 0.246 & 0.031 & 0.236 & $0.729 * * *$ & 0.191 & 0.084 & 0.221 \\
\hline $\begin{array}{l}\text { Farmer } \\
\text { associations }\end{array}$ & $0.501^{* *}$ & 0.222 & 0.256 & 0.286 & $\begin{array}{c}0.627^{*} \\
*\end{array}$ & 0.262 & $0.415^{*}$ & 0.227 & 0.104 & 0.281 \\
\hline \multicolumn{11}{|c|}{ Biophysical factors } \\
\hline Farm size & 0.512 & 0.044 & 0.070 & 0.055 & $0.099 *$ & 0.054 & -0.026 & 0.047 & 0.097 & 0.060 \\
\hline Soil fertility & $-0.436^{* *}$ & 0.186 & $-0.546^{* *}$ & 0.254 & -0.262 & 0.238 & $-0.439 * *$ & 0.193 & -0.120 & 0.233 \\
\hline Climate change & -0.542 & 0.207 & $-0.473^{*}$ & 0.272 & 0.354 & 0.277 & $0.407^{*}$ & 0.217 & $-0.513^{*}$ & 0.268 \\
\hline \multicolumn{11}{|c|}{ Institutional factors } \\
\hline Land tenure & 0.206 & 0.206 & -0.118 & 0.280 & -0.197 & 0.254 & -0.169 & 0.209 & $0.484^{* *}$ & 0.236 \\
\hline Training & 0.423 & 0.350 & 0.998 & 0.634 & -0.308 & 0.406 & $0.791^{* *}$ & 0.373 & -0.543 & 0.439 \\
\hline Constant & -2.002 & 0.706 & -2.996 & 1.045 & -2.21 & 0.879 & -1.672 & 0.734 & 0.605 & 0.816 \\
\hline $\begin{array}{l}\text { Number of } \\
\text { observations }\end{array}$ & & & 616.0 & 616.0 & & 616.0 & & 616.0 & & 616.0 \\
\hline$\overline{\text { Prob > chi2 }}$ & & & 0.000 & 0.001 & & 0.040 & & 0.000 & & 0.000 \\
\hline Log-likelihood & & & -396.85 & -248.1 & & -268.6 & & -381.6 & & -291.9 \\
\hline Pseudo R2 & & & 0.063 & 0.075 & & 0.050 & & 0.072 & & 0.084 \\
\hline LR chi2 (16) & & & 53.19 & 40.33 & & 28.48 & & 58.77 & & 53.75 \\
\hline \multirow{2}{*}{ Heteroskedasticity } & $\mathrm{Chi}^{2}$ & & 0.46 & & & & & & & \\
\hline & Prob $>\mathrm{chi}^{2}$ & & 0.497 & & & & & & & \\
\hline \multirow[t]{2}{*}{ Goodness of fit } & $\mathrm{Chi}^{2}$ & & 4.300 & & & & & & & \\
\hline & Prob $>$ chi $^{2}$ & & 0.829 & & & & & & & \\
\hline
\end{tabular}

Source: Own survey 2016; Coef. = Coefficient; $\mathrm{SE}=$ Standard error; statistically significant at the level of $\mathrm{p}<0.1 *$, $0.05^{* *}$, and $0.01^{* * *}$ 
Male-headed household decreased the probability of the smallholder farmer adopting minimum tillage. This can be explained by the fact that women conduct the majority of farm activities in Mozambique and will adopt minimum tillage due to the lower labor demand (Chompolola \& Kaonga, 2016; Mudiwa 2011). In Tanzania, Banjarnahor (2014), indicated that maleheaded households do not consider minimum tillage feasible in their fields. If the smallholder farmer was not aware of the declining soil fertility status of their fields, the adoption probability of minimum tillage decreased significantly (Aklilu \& de Graaff, 2006). The negative coefficient means that smallholder farmers might not see the negative effect of conventional practices on their plots in the long term and therefore do not acknowledge the need for conservation agricultural practices (e.g., minimum tillage).

Similarly, if the farmer was not aware of the changing climate, the adoption probability of minimum tillage also decreased significantly. A study done by Gjengedal (2016) reported that smallholder farmers' awareness of climate change was more likely to lead to adopting of CA practices as a mean to withstand extreme weather events in comparison with conventional tillage.

Factors influencing the adoption of cover crops: Farmers with less than ten years' experience were more likely to adopt cover crops (Table 3(C)). The perception of higher labor demand positively influenced the adoption of cover crops. Involvement in farmers' associations and farm size were positively correlated with adoption of cover crops, whereas reliance in conventional practices restricted the adoption of cover cropping

An increased labor capacity will increase the probability of adoption of cover crops. The likely reason is that smallholder farmers with large household members have more labor available for agricultural activities and contributes to the increased probability of adopting cover crops. These results corroborate with previous findings (e.g., Fentie et al., 2013), who reported that conservation farming practices are labor-intensive and require additional labor for adopters.

Membership of the household head to agricultural associations increased the probability of adopting cover crops significantly. This agrees with the finding of Mwangi et al., (2015) who indicated that farmers who were members of expert groups allow farmers to discuss and share knowledge and contributed to the adoption of cover crops.

Farm size cultivated significantly and positively influenced the adoption of cover crops. Larger farm size was correlated with the farmer being more likely to adopt cover crops practices in comparison with farmers with a small portion of land. Nyambose \& Jumbe (2013) argued that smallholder farmers with larger farms could allocate a part of their farm for CA practices. This could allow them to 'test' practices such as cover crops on portions of their farm. Farmers with smaller fields do not have this luxury.

Farming experience had a significant negative impact on the adoption of cover crops. The reason was that farmers who are more than ten years involved in agricultural activities might be reluctant to adopt new technologies compared to less experienced farmers. The effects of experience are linked to exposure to CA practices, making farmers with more experience critical in adopting cover crops. This result was consistent with the findings by Mudiwa (2011) and Mwangi et al., (2015) who found a negative relationship between the farming experience and adoption of conservation agriculture practices. In addition to the reluctance in adopting new technologies, the lack of suitable cover crops and drought-tolerant varieties and lack of management interventions were attributed to the non-adoption of cover crops in the aforementioned studies.

Factors influencing the adoption of crop rotations: Although adoption of crop rotations was negatively correlated to the age of the household head, the experience of the household head had a significant positive influence on the adoption of this practice (Table 3(D)). Access to communication assets (such as a mobile phone, television, and radio ownership), animal ownership, and involvement in group membership, as well as perception about climate change and participation in informal training (such as field day, demonstration plot), also influenced the adoption of crop rotations positively. The farmers did not consider labor to be more intensive when crop rotations are employed, and perception about changing soil fertility decreased the likelihood of adoption of crop rotations.

Older farmers preferred not to adopt crop rotation practices (Table 3(D)). In general, older farmers tend to be less flexible to new ideas and have shorter planning horizons when compared to their younger counterparts. Several other researchers (e.g., Miheretu \& Yimer, 2017; Teklewold \& Köhlin, 2011), also reported the negative 
relation between farmer age and adoption of sustainable agricultural practices.

Interestingly, the experience of the farmer was positively correlated to the adoption of crop rotation practices. Experience and age are, therefore, not directly related to this work. Farmers who have practised or exposed to conservation agriculture practices are in a better position to evaluate problems and increase their adoption (Wagayehu \& Lars, 2003; Alufah et al., 2012).

Group membership had a significantly positive influence on the adoption of crop rotation. Other studies have also indicated that there is a positive relationship between group membership and adoption of sustainable agriculture practices (such as crop rotation) (Nkamleu, 2007; Teklewold et al., 2013). These authors argued that group membership exposes smallholder farmers to a wide range of knowledge and gives them a better opportunity to have access to information, more trust, and cooperation which can increase adoption of new technologies.

The smallholder farmer awareness about rainfall changing patterns and the extreme temperature increased the likelihood of adoption significantly. This means that as the smallholder farmers become aware of the role of crop rotations in mitigating effects of climate change are more motivated to adopt crop rotation in their farms. This result is consistent with findings from Zambia by FAO (2017), who reported that crop rotation adoption, in the context of climate change, can build resilience and increases crop productivity. In addition, farmers who were not aware of the role of crop rotation for increased soil fertility were unlikely to adopt crop rotation practices. Kanyamuka (2017) showed that smallholder farmers' perception of soil fertility significantly influenced the adoption decision of the use of maize and legume rotation.

Adoption of crop rotation by smallholder farmers was found to be influenced positively by the ownership and access to media such as radio, television, and mobile phones. This is in line with the finding of Lwoga et al., (2011) and Nkhoma et al., (2017) who stated that the access to mass media (radio and cellular) was an adequate channel for acquiring information and knowledge in rural areas.

A negative and significant relationship was found between farmers who faced labor constraints and adoption of crop rotation. This meant that farmers who were not able to hire external labor were less likely to adopt crop rotation. This can be explained by the fact that crop rotation implies crop diversifications, and this is labor intensive and will require more labor to adopt. Smallholder farmers rely on family labor for agricultural activities and have low labor availability in adult equivalent. Exposure to formal and informal training had a significant and positive influence on the adoption of crop rotation. Therefore, it is expected the frequency of exposure to formal and informal training will have a positive correlation with the adoption of crop rotation. Past studies in different countries (e.g. Fentie et al., 2013; Kassie et al., 2009; Wagayehu \& Lars, 2003; Bisangwa, 2013) reported that participation in field days, number of contacts by extension agents, agricultural institutions of learning and research and development agents, have a positive correlation with adoption conservation practices.

Animal ownership reduces the risks associated with adopting new practices such as crop rotation. There was, therefore, a positive relationship between the number of livestock and adoption (Table 3(D)). Feyisa (2014), argued that livestock are a source of income and assets indicating the wealth status of the household, and it affects the adoption of soil and water conservation practices positively.

Factors influencing the adoption of intercropping: Female-headed households and households where the head was literate and depended solely on agriculture for their income were more likely to adopt intercropping practices (Table 3 (E)). Good land tenure systems (security), promoted the adoption of intercropping practices. However, the expected high labor demand and knowledge of changing rainfall patterns and extreme temperatures reduced the adoption of intercropping. Maize-legume intercropping was adopted to maximize land use and reduce risks of crop failure and were found to be more attractive compared to monocropping.

The awareness of changing rainfall patterns and extreme temperature impacted the adoption of intercropping negatively (Table 3 (E)) and significantly influenced the adoption of intercrops. These results are inconsistent with other studies, for example, Kassie et al. (2012), and Singh \& Singh (2017). These studies reported that intercropping as a climate-smart agricultural practice that can help smallholder farmers to reduce risk and improve crop yield productivity.

Female-headed households were more likely to adopt intercropping than male headed households (Table 3 
(E)). This is consistent with studies by Arslan et al. (2013) in Zambia, who found female-headed household increased the adoption of conservation farming practices (e.g., intercropping).

Farmers who were engaged in on-farm activities had more experience to determine which crop would be best intercropped with maize and is more likely to adopt intercropping practices compared to off-farm employment. A significantly positive relationship was found between farmers who had labor constraints and the adoption of intercrops. This meant that smallholder farmers who were able to hire external labor were more likely to adopt intercropping. Odendo et al., (2010) found that labor availability enhances the adoption probability in labor-intensive agricultural practices. McNamara et al. (1991) argued that off-farm activities compete for on-farm management time.

The results indicated that land security (ownership) has a positive relationship with the adoption of intercropping. This could be explained by the fact that CA practices benefits are not realized in a short time and due to tenure insecurity smallholder farmers will be less likely to make long term investment on the rented or leased plot. These results are consistent with the previous study by Ketema \& Bauer (2012) done in Ethiopia, who indicated that land tenure has a significant and positive influence in the adoption of intercropping. Education status of the household head increases smallholder farmer ability to access and use information related to conservation agriculture practices. Similar results were found by Bisangwa (2013), Feyisa (2014) and Bazezew, (2015) who concluded that an educated farmer was associated with the adoption of new agricultural practices.

\section{CONCLUSION AND RECOMMENDATIONS}

The study revealed that smallholder farmers untangle the full CA package and adopt only those relevant and suitable for their farming systems. For example, from the descriptive analysis, it was apparent that minimum tillage and cover crops were adopted by less than $18 \%$ of the respondents.

In general, the results demonstrate that the socioeconomic variables such as household size, animal ownership, communication assets, farmer associations and gender of the household head, and biophysical variables (perception about declining soil fertility) are determinants in the adoption of CA practices. It is worth emphasizing the importance of four variables, namely, household size, animal ownership, communication assets, and farmer associations that had positively contributed to the adoption of CA practices. Interestingly female headed households were more likely to adopt CA practices, whereas knowledge about declining soil fertility was not sufficient motivation for adoption CA practices. The latter suggests that more should be done in terms of creating awareness of the direct impact of degrading soil resources on the livelihoods of smallholder farmers.

The factors identified could be useful to design agriculture policies and projects aimed at the adoption of CA practices. For example, communications assets such as community radio and group membership played an important role as a channel of communication and sources of information for the dissemination of CA practices.

The econometric analysis of separated adoption of components of CA technology shows mixed findings on variables factors and the role they play in smallholder farmer decision to adopt separated components. This highlights that the adoption of components of CA is a complex issue which justifies more and site-specific research.

\section{ACKNOWLEDGEMENT}

The authors wish to thank the farmers from the six districts namely Lichinga and Cuamba (Niassa Province), Malema (Nampula province) Gurúè and Namarroi (Zambézia Province) and Inharrime (Inhambane province) for their valuable collaboration. Financial support from APPSA programme funded by the World Bank is genuinely acknowledged.

\section{REFERENCES}

Adeogun, A., Ajana, A. M., Ayinla, A., Yarhere, M. T., \& Adeogun, M. 0. (2008). Application of logit model in adoption decision: A study of hydrid clarias in Lagos State, Nigeria. American-Eurasian. Journal Agricultural and Environment Sciences, 4, 468472.

Alliance for a Green Revolution in Africa (AGRA). (2015). Africa Agriculture Status Report: Youth in Agriculture in Sub-Saharan Africa. Nairobi, Kenya. Issue No. 3.

Alufah, S., Shisanya, C. A., \& Obando, J. A. (2012). Analysis of factors influencing the adoption of soil and water conservation technologies in Ngaciuma Subcatchment, Kenya. African Journal of Basic \& Applied Science, 4, 172-185. 
Aklilu, A., \& de Graaff, J. (2006). Determinants of adoption and continued use of stone terraces for soil and water conservation in an Ethiopian highland watershed. Ecological Economics, 61(23),294-302.

Arslan, A., McCarthy, N., Lipper, L., Asfaw, S. \& Cattaneo, A. (2013). Adoption and intensity of adoption of conservation farming practices in Zambia. Agricultural Ecosystems \& Environment, 187, 7286.

Ayuya, O. I., Waluse, S. K., \& Gido, O. E. (2012). Multinomial logit analysis of smallscale farmers' choice of organic soil management practices in Bungoma County, Kenya. Current Research Journal of Social Sciences, 4, 314-322.

Bamire, A. S., Fabiyi, Y. L. \& Manyong, B. (2002). Adoption pattern of fertilizer technology among farmers in the ecological zones of southwestern Nigeria: a Tobit analysis. Australian Journal of Agricultural Research, 5, 901-910.

Banjarnahor, D. (2014). Adoption and adaptation of conservation agriculture in Tanzania southern highlands: lessons learned from Mshewe ward Mbeya region. Master's thesis: Department of Plant Sciences, Wageningen University.

Bazezew, H. A. (2015). Adoption of conservation agriculture practices: the case of Dangila District, Amhara Region, Ethiopia. Global Journal of Agricultural Economics Extension and Rural Development, 3, 295-307.

Berger, A., Fredrich, T., \& Kienzle, J. (2008). Soil Plant Growth and Production (pp. 115). Rome, Italy.

Bisangwa, E. (2013). The influence of conservation agriculture adoption on input demand and maize production in Butha Buthe, Lesotho. Master's thesis: Department of Agricultural and Resource Economics, University of Tennessee.

Bizunhe, M. A. (2012). Adoption of soil and water conservation practices on farmlands: The case of Karita Wuha watershed, west Belessa District, North Gondar, Ethiopia. Master's thesis: Indira Gandhi National Open University, Addis Ababa.

Chiputwa, B., Langintuo, S., \& Wall, W. P. (2011). Adoption of conservation agriculture technologies by smallholder farmers in the Shamva District of Zimbabwe: a tobit application. Department of Agricultural and Applied Economics. University of Georgia, Athens, USA. Paper accepted for the meeting of the Southern Agricultural Economics Associations (SAEA) in Texas, USA, Feb. 5-8.

Chompolola, A., \& Kaonga, O. (2016). Adoption of conservation agriculture in Zambia- The case of Chongwe District. Journal of Sustainable Development, 9 (3), 77-86.

Famba, S. (2010). Land degradation status: Mozambique country situation Appraisal. Presented at FAO Land Degradation Assessment meeting in Pretoria, South Africa.

FAO (Food and Agriculture Organization). (2017); Tackling climate change in Zambia and Malawi bringing together evidences and policy insights. The economic and Policy Innovation for ClimateSmart Agriculture Change (EPIC), FAO.

Fentie, D., Fufa, B., \& Bekele W. (2013). Determinants of the use of soil conservation technologies by smallholders' farmers: the case of Hulet Eju Enesie District, east Gojjam Zone., Ethiopia. Asian Journal of Agriculture Food Sciences, 1, 119-138.

Feyisa, Y. (2014). Assessment of factors affecting adoptions of water harvesting technology: The case of Damota Kebele, Haramaya Woreda, east Harerge zone, Oromia Region. Master's thesis: Haramaya University. Ethiopia.

Filipe, M., \& Kring, T. (2011). Agriculture and poverty reduction in Mozambique. Economic and policy analysis unit Brief. March. United Nation Development Programme (UNDP).

Gjengedal, M. (2016). Conservation agriculture in Gimbi, Ethiopia: benefits and barriers to adoptions; Master's thesis: Department of Sociology and Human Geography.The University of Oslo.

Giller, K. E., Witter, E., Corbeels, M., \& Titonell, P. (2009). Conservation agriculture and smallholder farming in Africa: the heretics' view. Field Crops Research, 114, 23-34.

Gowing, J. W., \& Palmer, M. (2008). Sustainable agricultural development in Subsaharan Africa: the case for a paradigm shift in land husbandry. Soil Use Management, 24, 92-99.

Grabowski, P. (2011). Constraints to adoption of conservation agriculture in the Angónia highlands of Mozambique: Perspectives from smallholder hand-hoe farmers. Master's thesis: Michigan State University.

Hobbs, P. R. (2007). Conservation agriculture: What is it, and why is it important for future sustainable food 
production? Journal of Agricultural Science, 145, 127-137.

Holden, S. T., \& Quiggin, J. (2016). Climate risk and statecontingent technology adoption: shocks, drought tolerance, and preferences. European Review of Agricultural Economics, 44, 285-308.

Idrisa, Y. L., Shehu, H., \& Ngamdu, M.B. (2012). Effects of adoption of improved maize seed on household food security in Gwoza Local Government Area of Borno State, Nigeria. Global Journal of Science Frontier Research, 12 (5-D).

Jacobs, A.J., van Tol, J.J. \& du Preez, C.C. (2018). Farmers perceptions of precision agriculture and the role of agricultural extension: a case study of crop farming in the Schweizer-Reneke region, South Africa. South African Journal of Agricultural Extension, 46(2), 107-118.

Kanyamuka, J. S. (2017). Adoption of integrated soil fertility management technologies and its effect on maize productivity: a case of the legume best bets project in Mkanakhoti extension planning area of kasungu District in central Malawi. Master's thesis: Lilongwe University of Agriculture and Natural Resources. Bunda - Malawi.

Kassie, M., Jaleta, M., Shiferaw, B., Mmbando, F., \& Muricho. (2012). Plot and household determinants of sustainable agricultural practices in rural Tanzania. Environment for development discussion paper - Resources for the future (RFF).

Kassie, M., Zikhali, P., Manjur, K., \& Edwards, S. (2009). Adoption of Organic farming techniques Evidences from a semi-arid region of Ethiopia. Environment for development discussion paper series. EfD DP 09-01.

Ketema, M. \& Bauer, S., 2012. "Factors Affecting Intercropping and Conservation Tillage Practices in Eastern Ethiopia," AGRIS on-line Papers in Economics and Informatics, Czech University of Life Sciences Prague, Faculty of Economics and Management, 4(1), 1-9, March.

Knowler, D., \& Bradshaw, B. (2007). Farmers' adoption of conservation agriculture: a review and synthesis of recent research. Food Policy, 32, 2548.

Lwoga, E. T., Stilwell, C., \& Ngulube, P. (2011). Access and use of agricultural information and knowledge in Tanzania. Library Review, 60, 383-395.

McNamara, K. T., Wetzstein, M. E., \& Douce, G.K. (1991).
Factors affecting peanut producer adoption of integrated pest management. Review of Agricultural Economics, 13, 129 - 139.

Mengstie, F. A. (2009). Assessment of adoption behaviour of soil and water conservation practices in Koga watershed, Highlands of Ethiopia. Master's thesis. Cornell University.

Miheretu, B. A., \& Yimer, A. A. 2017. Determinants of farmers' adoption of land management practices in Gelana sub-watershed of Northern highlands of Ethiopia. Ecological Processes, 6 (9), 1-11.

Ministério da Administração Estatal (MAE). (2005a). Perfil do Distrito de Inharrime, Província de Inhambane. Maputo.

Ministério da Administração Estatal (MAE). (2005b). Perfil do Distrito de Lichinga, Província de Niassa. Maputo.

Ministério da Administração Estatal (MAE). (2005c). Perfil do Distrito de Gúrue, Província de Zambézia. Maputo.

Ministério da Administração Estatal (MAE). (2005d). Perfil do Distrito de Malema, Província de Nampula. Maputo.

Mucavele, F. G. (2009). True contribution of agriculture to economic. Maputo, Mozambique: Food, Agriculture, and Natural Resources Policy Analysis Network. FARPAN.

Muchinapaya, T. (2012). The sustainability of conservation farming in the smallholder farming sector: a case of Guruve communal area in Zimbabwe. Master's thesis: Department of Agricultural Economics and Extension. University of Zimbabwe - Zimbabwe.

Mudiwa, B. (2011). A logit estimation of factors determining adoption of conservation farming by smallholder farmers in the semi-arid areas of Zimbabwe. Department of Agricultural Economics and Extension. University of Zimbabwe Zimbabwe

Mwangi, H. W., Kihurani, A. W., Wesonga, J. M., Ariga, E. S., \& Kanampiu, F. (2015). Factors influencing adoption of cover crops for weed management in Machakos and Makueni counties of Kenya. European Journal of Agronomy, 69, 1-9.

Ng`ombe, J., Kalinda, T., Tembo, G., \& Kuntashula, E. (2014). Econometric analysis of the factors that affect adoption of conservation farming practices by smallholder farmers in Zambia. Sustainable 
Development, 7, 124-138.

Nkala, P. (2012). Assessing the impacts of conservation agriculture on Farmer livelihoods in three selected communities in Central Mozambique. University of Natural Resources and Applied Life Sciences -Vienna.

Nkamleu, G. B. (2007). Modelling farmers' decisions on Integrated Soil Nutrient Management in SubSaharan Africa: A Multinomial Logit Analysis in Cameroon. In Bationo (Ed.), Advances in in Integrated Soil Fertility Management in SubSaharan Africa: Challenges and Opportunities (pp: 891-991). Springer Publishers, Netherlands.

Nkhoma, S., Kalinda, T., \& Kuntashula, E. (2017). Adoption and impact of conservation agriculture on smallholder farmers'crop productivity and Income in Luapula Province, Zambia. Journal of Agricultural Science, 9 (9), 168- 181.

Nyambose, W., \& Jumbe, C. B. L. (2013). Does conservation agricultture enhance household food security? Evidence from smallholder farmers in Nkhotakota in Malawi. Paper presented at the 4th International Conference of the African Association of Agriculture Economics September 22-25, Hammamet, Tunisia.

Odendo, M., Obare, G., \& Salasya, B. (2010). Determinants of the speed of adoption of soil fertility enhancing technologies in western Kenya. Contributed paper presented at the joint 3rd AAAE and 48th AEASA. Conference, Cape Town, South Africa, September 19-20, 2010.

Olayemi, J. K., \& Ikpi, A. E. (1995). Sustainable agriculture and economic development in Nigeria, Arlington. VA: ARSSRN, Winrock International Institute for Agricultural Development.

Okello, J. J. Gitonga, Z., Kirui, O., \& Njiraini, W. (2012). Drivers of use of information and communication technologies by farm households the case of smallholder farmers in Kenya. Journal of Agricultural Science, 4, 188-195.

Sarantakos, S. (1998). Social Research. Second Edition. Mac-Millan Education, South Yarra, Victoria.

Sheikh, A. D. Rehman, T., \& Yates. (2003). Logit models for identifying the factors that influence the uptake of new "no-tillage" technologies by farmers in the rice-wheat and cotton - Wheat farming system. Agricultural Systems, 75, 79-95.

Singh, R., \& Singh, G. S. (2017). Traditional agriculture: a Climate Smart approach for sustainable food production. Energy Ecological environment, 2 (5), 296-316.

StataCorp. (2017). Stata Software: Release 15. College Station, TX: StataCorp LP.

Tadesse, M., \& Belay, K. (2004). Factors influencing adoption of soil conservation measures in southern Ethiopia: the case of Gununo area. Journal of Agriculture and Rural Development in the Tropics and Subtropics, 105, 49-62.

Teklewold, H., \& Köhlin, G. (2011). Risk preferences as determinants of soil conservation decisions in Ethiopia. Journal of Soil and Water Conservation, 66, 87-96.

Teklewold, H., Kassie, M., \& Shiferaw, B. (2013). Adoption of multiple sustainable agricultural practices in rural Ethiopia. Journal of Agricultural Economics, 64 (3), 597-623.

Thierfelder, C., Mombeyarar, T., Mango, N., \& Rusinamhodzi, L. (2013). Integration of conservation agriculture in smallholder farming system of southern Africa: identification of key entry points. International Journal of Agricultural Sustainability, 11, 317-330.

Vanlauwe, B., Coyne, D., Gockowski, J., Hauser, S., Huising, J., Masso, C., Nziguheba, G., Schut, M., \& Van Austen, P. (2014). Sustainable intensification and the African smallholder farmer. Current Opinion in Environmental Sustainability, 8, 15-22.

Wagayehu, B., \& Lars, D. (2003). Soil and water conservation decision of subsistence farmers in the eastern highland of Ethiopia: a case study of the Hunde-Lafto. Journal of Agricultural Economics, 18, 125-133.

World Bank, The. (2006). Mozambique Agriculture Development Strategy. Stimulating smallholder agricultural growth. Report No. 32416 - MZ Agriculture, Environment and Social Development Unit, World Bank, Washington Dc, USA. 
Publisher's note: EScience Press remains neutral with regard to jurisdictional claims in published maps and institutional affiliations.

(c)

Open Access This article is licensed under a Creative Commons Attribution 4.0 International License, which permits use, sharing, adaptation, distribution and reproduction in any medium or format, as long as you give appropriate credit to the original author(s) and the source, provide a link to the Creative Commons license and indicate if changes were made. The images or other third-party material in this article are included in the article's Creative Commons license, unless indicated otherwise in a credit line to the material. If material is not included in the article's Creative Commons license and your intended use is not permitted by statutory regulation or exceeds the permitted use, you will need to obtain permission directly from the copyright holder. To view a copy of this license, visit http://creativecommons.org/licenses/by/4.0/.

(C) The Author(s) 2019. 